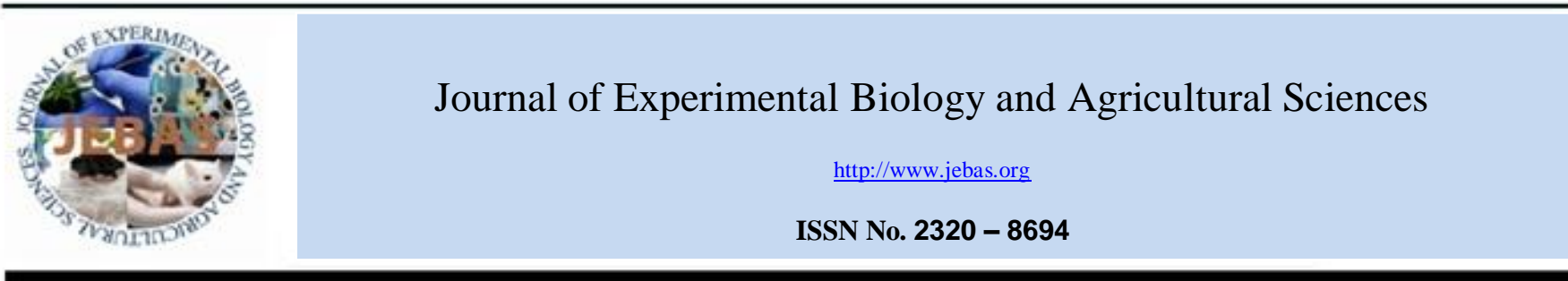

\title{
CUMULATIVE EFFECT OF SEWAGE SLUDGE AND FERTILIZERS APPLICATION ON ENHANCING SOIL MICROBIAL POPULATION UNDER RICE - WHEAT CROPPING SYSTEM
}

\author{
H. S. Jatav ${ }^{1 *}$, S. K. Singh ${ }^{2}$, J. S. Yadav ${ }^{3}$ \\ ${ }^{1}$ Research Scholar, Department of Soil Science and Agricultural Chemistry, Institute of Agricultural Sciences, Banaras Hindu University Varanasi, Uttar Pradesh, \\ India -221005 . \\ ${ }^{2}$ Professor, Department of Soil Science and Agricultural Chemistry, Institute of Agricultural Sciences, Banaras Hindu University Varanasi, Uttar Pradesh, India -221 005. \\ ${ }^{3}$ Department of Botany, Institute of Science, Banaras Hindu University Varanasi, Uttar Pradesh, India -221 005
}

Received - February 16, 2018; Revision - May 01, 2018; Accepted - June 16, 2018

Available Online - June 20, 2018

DOI: http://dx.doi.org/10.18006/2018.6(3).538.543

KEYWORDS

Sewage sludge

Fertilizers

Soil microbial population

Rice -Wheat system

\begin{abstract}
A field experiment in randomised block design was conducted at Agriculture Research Farm, Banaras Hindu University, Varanasi, U.P. (India) to find out the effect of conjoint application of sewage sludge and fertilizers on soil microbial population of rice-wheat cropping system (RWCS). Total ten treatments consisting of sewage sludge and fertilizer was formulated. The study demonstrated that increase in bacterial population $\left(10^{-6} \mathrm{cfu} \mathrm{g}^{-1}\right)$ in treatment containing $30 \mathrm{tha}^{-1} \mathrm{SS}+100 \% \mathrm{RDF}$ where, $30 \mathrm{ton} \mathrm{ha}^{-1}$ sewage sludge was applied along with $100 \%$ RDF followed by treatments $20 \mathrm{t} \mathrm{ha}^{-1} \mathrm{SS}+100 \% \mathrm{RDF}$ where, 20 ton $^{\mathrm{ha}^{-1}}$ sewage sludge was applied along with $100 \%$ RDF. The bacterial population subsequently decreased in remaining three crops after taking $\mathrm{I}^{\mathrm{st}}$ rice. In case of Fungi $\left(10^{-4} \mathrm{cfu} \mathrm{g}^{-1}\right)$ the maximum population was in $30 \mathrm{t} \mathrm{ha}^{-1}$ Sewage sludge applied with $100 \% \mathrm{RDF}$ which was followed by 20 ton $\mathrm{ha}^{-1}$ sewage sludge was applied along with $100 \%$ RDF where as Actinomycetes was maximum in 30 $\mathrm{t} \mathrm{ha}^{-1}$ Sewage sludge applied with $100 \%$ RDF. There was depletion of microbial population in subsequent three crops after first rice crop in which sewage sludge was added. The minimum microbial population was found in treatment without fertilizer and sewage sludge in rice wheat cropping system.
\end{abstract}

* Corresponding author

E-mail: hanumaniasbhu@gmail.com (H. S. Jatav)

Peer review under responsibility of Journal of Experimental Biology and Agricultural Sciences.

Production and Hosting by Horizon Publisher India [HPI] (http://www.horizonpublisherindia.in/).

All rights reserved.
All the article published by Journal of Experimental Biology and Agricultural Sciences is licensed under a Creative Commons Attribution-NonCommercial 4.0 International License Based on a work at www.jebas.org.

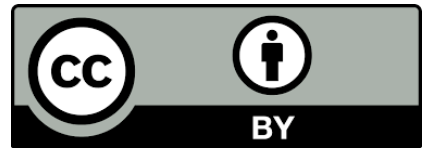




\section{Introduction}

The worlds' population is increasing and concentrating in urban centres. This trend is particularly intense in developing countries, where an additional 2.1 billion people are expected to be living in cities by 2030 (United Nations, 2014; United Nations, 2015). The fact itself says that population is burgeoning with an alarming rate coupled with the problems of soil health, climate change and food security, and this compel us for the adoption of intensive farming system to supply the food requirements and address the challenges we will face by 2050 . The living body soil is a non-renewable resource because its formation takes thousands of years. It may be considered that the native inherent capacity of this versatile and worthy natural resource may get exhausted in order to fulfil our daily food demands. In the coming time we have to adopt new technological interventions or cropping systems to supply our increasing food demands, out of which intensive cultivation is one of them. The intensive cultivation will accelerate the nutrient depletion rate from soil that will lead to depletion of native fertility status which will emerge in the form of deficiency or lack of SOC (soil organic carbon) (Lal et al., 2007; Lal, 2016). In many countries the deficiency of macro or micronutrients is emerging in soil at an alarming level like India and Africa. To overcome from this problem, researcher and scientific communities need to pay more attention not only on managing soil fertility but also on recycling of the wastes generated in cities. Depletion of organic matter in soil discourages activity of soil micro flora responsible for decomposition of organic matter to enrich soil fertility (Sharma \& Subehila, 2014). The high nutrients and organic matter contents of sewage sludge make it an excellent fertilizer to enhance soil fertility and crop production. However, presence of heavy metals may be a problem for utilization of sewage in agriculture sector, but it's utilisation in a proper manner makes it suitable to fulfil the nutritional requirement of the crops (Smith, 2009; Cieślik et al., 2015). The management and disposal of sewage sludge in an economically and environmentally acceptable manner, is one of the society's most persistent problem. The previous study suggested that if the dose of sewage sludge exceed from 45 ton ha ${ }^{-1}$, there could be chance to build-up of heavy metals (Latare et al., 2014). So, the dose of sewage sludge in present study was reduced to 20 to 30 ton $^{-1}$. Soil organism acts as primary driving agents of nutrient cycling, regulating the dynamics of soil organic matter, soil carbon sequestration greenhouse gas emission, modifying soil structure and water regimes, enhancing the amount of nutrient acquisition by vegetation, conferring stress tolerance, resisting pathogens and improving plant health (Magdoff \& Van Es, 2009).

\section{Materials and methods}

The field experiment was conducted in randomised block design on alluvial soil representing an Inceptisol (Typic Ustochrept) during July-2015 to April- 2017, at Agriculture Research Farm, Institute of Agricultural Sciences, Banaras Hindu University, Varanasi (U.P.) using Rice ( $c v$. Arize- 6444) and Wheat ( $c v$. Pusa Gautmi, HD-3086) as test crop. The previously rice and wheat cropping system was followed subsequently. The Varanasi, India is located between $25^{\circ} 19^{\prime}$ North latitude and $83^{\circ} 10^{\prime}$ East longitudes. The initial properties of experimental soil and sewage sludge are presented in Table 1. The sewage sludge (Figure 1) was collected from Bhagwanpur sewage treatments plant (STPs). The

Table 1 Bio-chemical properties of experimental site $(0-15 \mathrm{~cm})$ and sewage sludge

\begin{tabular}{|c|c|c|}
\hline Properties & Initial Soil & Sewage sludge \\
\hline pH (Soil:water, 1:2.5) & $8.24 \pm 0.5$ & $6.58 \pm 0.62$ \\
\hline $\mathrm{EC}\left(\mathrm{dS} \mathrm{m} \mathrm{m}^{-1}\right)$ & $0.15 \pm 0.01$ & $2.49 \pm 0.02$ \\
\hline Organic C $(\%)$ & $0.46 \pm 0.04$ & $8.19 \pm 0.59$ \\
\hline Available $\mathrm{N}\left(\mathrm{mg} \mathrm{kg}^{-1}\right)$ & $63.27 \pm 2.24$ & $155.43 \pm 4.23$ \\
\hline Available $\mathrm{P}\left(\mathrm{mg} \mathrm{kg}^{-1}\right)$ & $7.78 \pm 0.12$ & $68.56 \pm 3.15$ \\
\hline Available $\mathrm{K}\left(\mathrm{mg} \mathrm{kg}^{-1}\right)$ & $59.26 \pm 2.26$ & $174.19 \pm 5.85$ \\
\hline Bacteria $10^{-6} \mathrm{cfu} \mathrm{g}^{-1}$ soil & $14.50 \pm 0.29$ & $38.65 \pm 2.54$ \\
\hline Fungi $10^{-4} \mathrm{cfu} \mathrm{g}^{-1}$ soil & $7.20 \pm 0.21$ & $24.55 \pm 3.65$ \\
\hline Actinomycetes $10^{-5} \mathrm{cfu} \mathrm{g}^{-1}$ soil & $17.25 \pm 0.35$ & $39.20 \pm 2.84$ \\
\hline
\end{tabular}

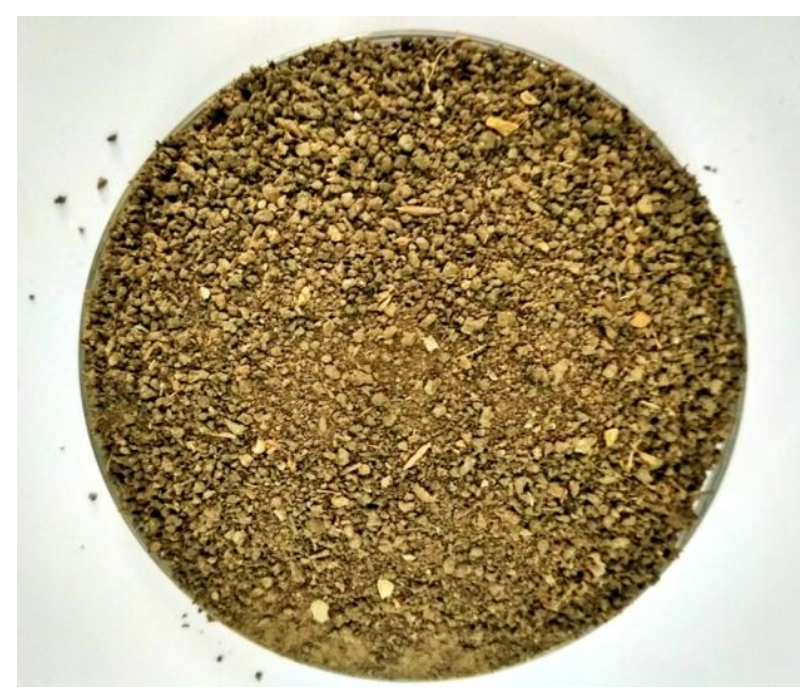

Figure 1 Experimental material sewage sludge collected from Bhagwanpur Sewage Treatment Plants (STPs) after dry 
sewage sludge was applied at initial stage before transplanting of first rice crop and there after only graded level of recommended dose of fertilizer was applied in remaining three crops. The post harvest soil samples of each crop were stored at low temperature in a freezer (Temperature $10-15{ }^{\circ} \mathrm{C}$ ) and used for measurement of different soil biological properties. The population of bacteria, fungi and actinomycetes in post harvest soil was determined by serial dilution of soil and plating technique using AsparagineMannitol agar medium (Thornton, 1922); Rose Bengal streptomycin agar medium (Martin, 1950) and Ken Knight and Munaier's medium by pour plate method (Chhonkar et al., 2002), respectively. The initial soil samples $(0-15 \mathrm{~cm})$ were subjected to analyzed for $\mathrm{pH}$ and $\mathrm{EC}\left(\mathrm{dS} \mathrm{m}^{-1}\right)$ in 1:2.5 (soils: water suspension) (Sparks, 1996); organic carbon by Walkley \& Black (1934) method; available $\mathrm{N}$ by alkaline potassium permanganate method (Subbiah \& Asija, 1956), available P by sodium bicarbonate (Olsen et al., 1954) with spectrophotometer, available $\mathrm{K}$ by ammonium acetate extraction (Jackson, 1973) using flame photometer. Sewage sludge was also digested in di-acid and analyzed for $\mathrm{P}, \mathrm{K}$ and for the determination of total $\mathrm{N}$ sludge was digested in concentrated $\mathrm{H}_{2} \mathrm{SO}_{4}$. The data were subjected to one way analysis of variance (ANOVA $P=0.05$ ) using SPSS version 22 software. Duncan's Multiple Range Test (Duncan, 1955) was performed to test the significance of difference between the treatments.

\section{Results and discussion}

\subsection{Bacterial Population:}

The data presented in table 2 explained that effect of conjoint application of sewage sludge (SS) and fertilizers on bacterial population $\left(10^{-6} \mathrm{cfu}^{-1}\right.$ soil) in post harvest soils of RWCS. Application of sewage sludge in soil increased the population of bacteria which ranged from $14.33\left(10^{-6} \mathrm{cfu} \mathrm{g}^{-1}\right.$ soil) to $34.97\left(10^{-6}\right.$

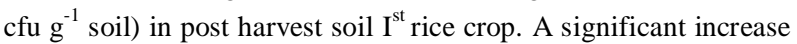
in bacterial $\left(10^{-6} \mathrm{cfu} \mathrm{g}^{-1}\right.$ soil) population was observed over RDF to the treatments in which 20 to and 30 ton $^{-1} \mathrm{~h}^{-1}$ sewage sludge was applied. The minimum bacterial population was observe in treatment without fertilizer which was $7.43\left(10^{-6} \mathrm{cfu}^{-1}\right.$ soil $)$ in post harvest soil (PHS) OF II $^{\text {nd }}$ wheat crop. The maximum bacterial population was found in treatment containing 30 ton ha ${ }^{-1}$ SS along with $100 \%$ RDF which was $34.72\left(10^{-6} \mathrm{cfu} \mathrm{g}^{-1}\right.$ soil $)$, this population reduced to 24.04 in II $^{\text {nd }}$ wheat crop. Rest of the treatments are showing either similar or at par the first rice crop. One time application of sewage sludge before first rice crop leads to a sharpe increase in population of bacteria but a decline in its population was observed with the subsequent cropping. It was reported that sewage sludge is rich source of organic carbon as well as micro and macro nutrients which release nutrients slowly as it decompose slowly (Latare \& Singh 2013; Latere et al., 2014; Jatav et al., 2016). The enhancement in bacterial population was found due to application of sewage sludge as sewage sludge is

Table 2 Effect of conjoint application of sewage sludge and fertilizers on bacterial population $\left(10^{-6} \mathrm{cfu}^{-1}\right.$ soil $)$ in post harvest soils

\begin{tabular}{|c|c|c|c|c|}
\hline \multirow{2}{*}{ Treatments* } & \multicolumn{2}{|c|}{$2015-2016$} & \multicolumn{2}{|c|}{ 2016-2017 } \\
\hline & I-Rice & I-Wheat & II-Rice & II-Wheat \\
\hline Without fertilizer & $14.33 \pm 0.58^{\mathrm{a}}$ & $11.92 \pm 0.79^{\mathrm{a}}$ & $8.42 \pm 0.74^{\mathrm{a}}$ & $7.43 \pm 0.27^{\mathrm{a}}$ \\
\hline $\operatorname{RDF}(100 \%)$ & $23.72 \pm 1.20^{\mathrm{b}}$ & $22.16 \pm 0.76^{\mathrm{b}}$ & $21.26 \pm 1.19^{\mathrm{b}}$ & $18.47 \pm 0.60^{\mathrm{b}}$ \\
\hline $20 \mathrm{tha}^{-1} \mathrm{SS}+\mathrm{RDF}(100 \%)$ & $32.97 \pm 1.35^{\mathrm{de}}$ & $30.72 \pm 1.59^{\mathrm{de}}$ & $26.65 \pm 0.61^{\mathrm{c}}$ & $23.18 \pm 0.82^{\mathrm{d}}$ \\
\hline $30 \mathrm{tha}^{-1} \mathrm{SS}+\mathrm{RDF}(100 \%)$ & $34.72 \pm 1.19^{\mathrm{e}}$ & $31.73 \pm 1.15^{\mathrm{e}}$ & $27.38 \pm 0.90^{\mathrm{c}}$ & $24.04 \pm 0.32^{\mathrm{d}}$ \\
\hline $20 \mathrm{t} \mathrm{ha}^{-1} \mathrm{SS}+\mathrm{RDF}(50 \%)$ & $26.91 \pm 0.83^{\mathrm{bc}}$ & $24.93 \pm 0.82^{\mathrm{bc}}$ & $21.43 \pm 0.82^{\mathrm{b}}$ & $19.11 \pm 0.34^{\mathrm{bc}}$ \\
\hline $20 \mathrm{t} \mathrm{ha}^{-1} \mathrm{SS}+\mathrm{RDF}(60 \%)$ & $28.57 \pm 0.98^{\mathrm{bc}}$ & $26.90 \pm 0.65^{\mathrm{cd}}$ & $23.40 \pm 0.65^{\mathrm{bc}}$ & $20.19 \pm 0.65^{\mathrm{bcc}}$ \\
\hline $20 \mathrm{tha}^{-1} \mathrm{SS}+\mathrm{RDF}(70 \%)$ & $29.81 \pm 0.35^{\text {cd }}$ & $26.99 \pm 0.90^{\text {cd }}$ & $23.70 \pm 0.71^{\mathrm{bc}}$ & $20.49 \pm 0.71^{\text {bcd }}$ \\
\hline $30 \mathrm{t} \mathrm{ha}^{-1} \mathrm{SS}+\mathrm{RDF}(50 \%)$ & $29.43 \pm 1.97^{\mathrm{cd}}$ & $27.12 \pm 1.91^{\mathrm{cd}}$ & $23.62 \pm 1.91^{\mathrm{bc}}$ & $20.56 \pm 2.04^{\mathrm{bcc}}$ \\
\hline $30 \mathrm{tha}^{-1} \mathrm{SS}+\mathrm{RDF}(60 \%)$ & $29.59 \pm 2.07^{\mathrm{cd}}$ & $27.32 \pm 1.8^{\mathrm{cd}}$ & $24.64 \pm 2.68^{\mathrm{bc}}$ & $21.82 \pm 2.16^{\mathrm{bcc}}$ \\
\hline $30 \mathrm{tha}^{-1} \mathrm{SS}+\mathrm{RDF}(50 \%)$ & $30.26 \pm 0.53^{\mathrm{cd}}$ & $28.21 \pm 0.57^{\text {cde }}$ & $24.91 \pm 0.41^{\mathrm{bc}}$ & $22.93 \pm 0.36^{\mathrm{cd}}$ \\
\hline
\end{tabular}

Value given in table is mean of three replicates; Mean \pm Standard error. Values with same letter differ non-significantly $(P>0.05)$. Different letters for each parameter show significant difference at $p<0.05$; RDF-Recommended dose of fertilizer, SS-Sewage sludge, Rice $100 \%$ RDF 150:60:60 kg N: $\mathrm{P}_{2} \mathrm{O}_{5}: \mathrm{K}_{2} \mathrm{O} \mathrm{ha}{ }^{-1}$; Wheat 100\% RDF 120:60:60 kg N:P $\mathrm{O}_{5}: \mathrm{K}_{2} \mathrm{O} \mathrm{ha}{ }^{-1}$ ) 
rich source of organic carbon and addition of organic matter in soil provide more carbon substrate for growth of microbes. The incensement in microbial population by addition of organic matter has also reported by Kamlesh et al. (1991) and Rajshree \& Piliai (2002). Singh et al. (2014) also reported that application of organic and inorganic sources of nutrients significantly affected the population of fungi, bacteria and actinomycetes.

\subsection{Fungal Population}

The data on fungal population $\left(10^{-4} \mathrm{cfu} \mathrm{g}^{-1}\right.$ soil) is presented in Table 3 and Figure 2. The fungal population ranged from 8.17 to $20.38\left(10^{-4} \mathrm{cfu} \mathrm{g}^{-1}\right.$ soil) in post harvest soil of being the minimum in control where no treatment was applied. The study showed a significant enhancement of microbial population with application of sewage sludge along with recommended dose of fertilizers. The treatments containing 20 or $30 \mathrm{t} \mathrm{ha}^{-1} \mathrm{SS}$ and 50-70\% RDF have similar fungal population whereas the treatment containing $20 \mathrm{t}$ $\mathrm{ha}^{-1} \mathrm{SS}+100 \%$ RDF and $30 \mathrm{t} \mathrm{ha}^{-1} \mathrm{SS}+100 \%$ RDF show significantly higher fungal population over the RDF. The decrease in fungal population was recorded with subsequent cropping due to depletion of organic matter as sewage sludge was only applied only in $\mathrm{I}^{\text {st }}$ rice crop only. Sewage sludge enhanced the microbial population in soil because it is not only rich source of organic carbon but also provide the essential nutrients for growth and development of microbes.

Table 3 Effect of conjoint application of sewage sludge and fertilizers on fungal population (10-4 cfu g-1 soil) in post harvest soils of rice-wheat cropping system (RWCS)

\begin{tabular}{|c|c|c|c|c|}
\hline \multirow{2}{*}{ Treatments* } & \multicolumn{2}{|c|}{ 2015-2016 } & \multicolumn{2}{|c|}{ 2016-2017 } \\
\hline & I-Rice & I-Wheat & II-Rice & II-Wheat \\
\hline Without fertilizer & $8.17 \pm 0.60^{\mathrm{a}}$ & $6.98 \pm 0.24^{\mathrm{a}}$ & $5.18 \pm 1.06^{\mathrm{a}}$ & $4.95 \pm 1.24^{\mathrm{a}}$ \\
\hline RDF (100\%) & $12.85 \pm 1.11^{\mathrm{b}}$ & $11.58 \pm 0.35^{\mathrm{b}}$ & $10.30 \pm 0.63^{b}$ & $10.25 \pm 0.46^{\mathrm{b}}$ \\
\hline $20 \mathrm{t} \mathrm{ha}^{-1} \mathrm{SS}+\mathrm{RDF}(100 \%)$ & $18.63 \pm 0.75^{\text {ef }}$ & $17.71 \pm 0.39^{\mathrm{ef}}$ & $16.71 \pm 0.75^{\mathrm{de}}$ & $15.80 \pm 0.21^{\mathrm{e}}$ \\
\hline $30 \mathrm{t} \mathrm{ha}^{-1} \mathrm{SS}+\mathrm{RDF}(100 \%)$ & $20.38 \pm 0.60^{\mathrm{f}}$ & $19.72 \pm 0.23^{\mathrm{f}}$ & $18.46 \pm 0.66^{\mathrm{e}}$ & $18.08 \pm 0.24^{\mathrm{f}}$ \\
\hline $20 \mathrm{tha}^{-1} \mathrm{SS}+\mathrm{RDF}(50 \%)$ & $13.64 \pm 0.29^{\mathrm{bc}}$ & $13.20 \pm 0.57^{\mathrm{bc}}$ & $11.27 \pm 0.58^{\mathrm{b}}$ & $11.01 \pm 0.70^{\mathrm{bc}}$ \\
\hline $20 \mathrm{tha}^{-1} \mathrm{SS}+\mathrm{RDF}(60 \%)$ & $14.23 \pm 0.32^{\mathrm{bcd}}$ & $13.51 \pm 0.54^{\mathrm{bc}}$ & $12.31 \pm 0.38^{\mathrm{bc}}$ & $12.28 \pm 0.23^{\mathrm{cd}}$ \\
\hline $20 \mathrm{t} \mathrm{ha}^{-1} \mathrm{SS}+\mathrm{RDF}(70 \%)$ & $15.48 \pm 0.99^{\mathrm{bcd}}$ & $14.46 \pm 0.89^{\text {bcd }}$ & $13.55 \pm 0.95^{\text {bcd }}$ & $12.79 \pm 0.13^{\mathrm{cd}}$ \\
\hline $30 \mathrm{t} \mathrm{ha}^{-1} \mathrm{SS}+\mathrm{RDF}(50 \%)$ & $15.10 \pm 1.34^{\mathrm{bcd}}$ & $14.41 \pm 1.53^{\text {bcd }}$ & $13.17 \pm 1.35^{\mathrm{bc}}$ & $12.76 \pm 1.01^{\mathrm{cd}}$ \\
\hline $30 \mathrm{t} \mathrm{ha}^{-1} \mathrm{SS}+\mathrm{RDF}(60 \%)$ & $16.26 \pm 1.20^{\text {cde }}$ & $15.25 \pm 1.57^{\text {cde }}$ & $13.33 \pm 1.55^{\mathrm{bc}}$ & $12.73 \pm 0.66^{\mathrm{cd}}$ \\
\hline $30 \mathrm{t} \mathrm{ha}^{-1} \mathrm{SS}+\mathrm{RDF}(50 \%)$ & $17.28 \pm 1.42^{\mathrm{de}}$ & $16.93 \pm 1.65^{\mathrm{def}}$ & $15.01 \pm 1.72^{\text {cd }}$ & $13.78 \pm 0.53^{\mathrm{d}}$ \\
\hline
\end{tabular}

Value given in table is mean of three replicates; Mean \pm Standard error. Values with same letter differ non-significantly $(P>0.05)$. Different letters for each parameter show significant difference at $p<0.05$; RDF-Recommended dose of fertilizer, SS-Sewage sludge, Rice 100\% RDF 150:60:60 kg N:P $\mathrm{P}_{2}: \mathrm{K}_{2} \mathrm{O} \mathrm{ha}^{-1}$; Wheat 100\% RDF 120:60:60 kg N:P $\mathrm{P}_{5}: \mathrm{K}_{2} \mathrm{O} \mathrm{ha}{ }^{-1}$ )

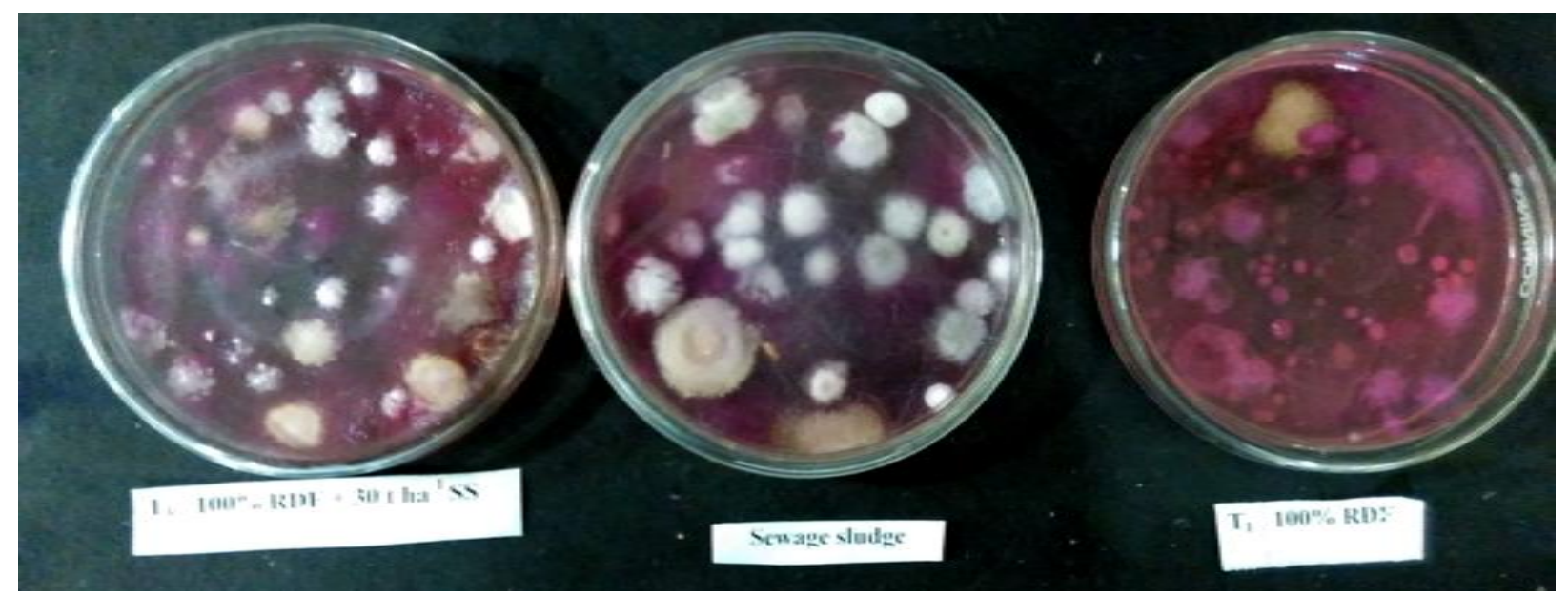

Figure 2 Fungal population (10-4 cfu g-1 soil) in post harvest soils of First Rice crop in treatment compared with Sewage sludge and $100 \%$ RDF

Journal of Experimental Biology and Agricultural Sciences http://www.jebas.org 
Table 4 Effect of conjoint application of sewage sludge and fertilizers on Actinomycetes population $\left(10^{-5} \mathrm{cfu} \mathrm{g}^{-1}\right.$ soil $)$ in post harvest soils of rice-wheat cropping system (RWCS)

\begin{tabular}{|ccccc|}
\hline \multirow{2}{*}{ Treatments* } & & & $2016-2017$ \\
Without fertilizer & I-Rice & I-Wheat & II-Rice & II-Wheat \\
\hline RDF $(100 \%)$ & $17.20 \pm 1.10^{\mathrm{a}}$ & $12.92 \pm 0.45^{\mathrm{a}}$ & $10.18 \pm 0.53^{\mathrm{a}}$ & $9.03 \pm 0.50^{\mathrm{a}}$ \\
\hline $20 \mathrm{t} \mathrm{ha}^{-1} \mathrm{SS}+\operatorname{RDF}(100 \%)$ & $24.29 \pm 1.42^{\mathrm{b}}$ & $20.49 \pm 1.03^{\mathrm{b}}$ & $18.84 \pm 1.02^{\mathrm{b}}$ & $17.33 \pm 0.65^{\mathrm{b}}$ \\
\hline $30 \mathrm{t} \mathrm{ha}^{-1} \mathrm{SS}+\operatorname{RDF}(100 \%)$ & $36.55 \pm 0.90^{\mathrm{fg}}$ & $27.68 \pm 0.89^{\mathrm{c}}$ & $25.12 \pm 0.89^{\mathrm{d}}$ & $24.34 \pm 0.78^{\mathrm{d}}$ \\
\hline $20 \mathrm{t} \mathrm{ha}^{-1} \mathrm{SS}+\operatorname{RDF}(50 \%)$ & $38.53 \pm 0.73^{\mathrm{g}}$ & $32.69 \pm 1.42^{\mathrm{d}}$ & $29.86 \pm 1.46^{\mathrm{e}}$ & $27.17 \pm 0.38^{\mathrm{e}}$ \\
\hline $20 \mathrm{t} \mathrm{ha}^{-1} \mathrm{SS}+\operatorname{RDF}(60 \%)$ & $27.32 \pm 0.58^{\mathrm{bc}}$ & $21.06 \pm 0.39^{\mathrm{b}}$ & $19.09 \pm 0.22^{\mathrm{bc}}$ & $17.53 \pm 0.27^{\mathrm{b}}$ \\
\hline $20 \mathrm{t} \mathrm{ha}^{-1} \mathrm{SS}+\operatorname{RDF}(70 \%)$ & $28.47 \pm 0.65^{\mathrm{cd}}$ & $21.35 \pm 0.49^{\mathrm{b}}$ & $19.28 \pm 0.13^{\mathrm{bc}}$ & $17.60 \pm 0.92^{\mathrm{b}}$ \\
\hline $30 \mathrm{t} \mathrm{ha}^{-1} \mathrm{SS}+\operatorname{RDF}(50 \%)$ & $28.88 \pm 0.36^{\mathrm{cd}}$ & $23.60 \pm 1.18^{\mathrm{b}}$ & $21.04 \pm 1.18^{\mathrm{bc}}$ & $19.50 \pm 1.18^{\mathrm{b}}$ \\
\hline $30 \mathrm{t} \mathrm{ha}^{-1} \mathrm{SS}+\operatorname{RDF}(60 \%)$ & $29.15 \pm 1.97^{\mathrm{cd}}$ & $22.65 \pm 2.01^{\mathrm{b}}$ & $20.09 \pm 2.01^{\mathrm{bc}}$ & $18.55 \pm 2.01^{\mathrm{b}}$ \\
\hline $30 \mathrm{t} \mathrm{ha}^{-1} \mathrm{SS}+\operatorname{RDF}(50 \%)$ & $31.22 \pm 0.82^{\mathrm{de}}$ & $24.40 \pm 1.80^{\mathrm{bc}}$ & $22.40 \pm 0.72^{\mathrm{cd}}$ & $20.37 \pm 1.08^{\mathrm{bc}}$ \\
\hline & $34.28 \pm 1.50^{\mathrm{ef}}$ & $27.70 \pm 1.75^{\mathrm{c}}$ & $24.41 \pm 0.91^{\mathrm{d}}$ & $22.87 \pm 0.91^{\mathrm{cd}}$ \\
\hline
\end{tabular}

Value given in table is mean of three replicates; Mean \pm Standard error. Values with same letter differ non-significantly $(P>0.05)$. Different letters for each parameter show significant difference at $p<0.05$; RDF-Recommended dose of fertilizer, SS-Sewage sludge, Rice $100 \%$ RDF 150:60:60 kg N: $\mathrm{P}_{2} \mathrm{O}_{5}: \mathrm{K}_{2} \mathrm{O} \mathrm{ha}{ }^{-1}$; Wheat 100\% RDF 120:60:60 kg N: $\mathrm{P}_{2} \mathrm{O}_{5}: \mathrm{K}_{2} \mathrm{O} \mathrm{ha}{ }^{-1}$ )

Result of the study revealed that the application of sewage sludge enhancemed fungal population which provide or solubilise the essential enzyme and nutrients for growth and development of plant. Sewage sludge was more effective in causing significant increase in microbial population. This might to be explained in the light of the heterotrophic nutritional behaviour of micro organism in soil. The significant and positive relationship of organic carbon with microorganism indicates that the increase in fungal population of soil may be due to high organic matter build up with the regular addition of sewage sludge (Mahajan et al., 2007).

\subsection{Actinomycetes population}

The data showing the Actinomycetes population $\left(10^{-5} \mathrm{cfu} \mathrm{g}^{-1}\right.$ soil $)$ is presented in Table 4 . The population of actinomycetes ranged from 17.20 to $38.55\left(10^{-5} \mathrm{cfu} \mathrm{g}^{-1}\right.$ soil). The observation showed that the enhancement in actinomycetes population in soil was found due to application of sewage sludge. The maximum population of actinomycetes was significant with the application of $30 \mathrm{ton}^{-1}$ hectare sewage sludge and this was followed by 20 ton $^{-}$ ${ }^{1}$ hectare along with $100 \%$ RDF in all four crops of rice and wheat taken during two cropping cycle. The treatments containing 20 or $30 \mathrm{t} \mathrm{ha}^{-1}$ SS along with 50-70\% RDF have similar or at par actinomycetes population in PHS of $\mathrm{I}^{\text {st }}$ where as in case of $\mathrm{I}^{\text {st }}$ wheat the treatment 30 and 20 ton $^{-1}$ hectare sewage sludge along with RDF are superior and rest treatments are not significantly different to each other. The depletion of actinomycetes population was observed as in the last crop (II ${ }^{\text {nd }}$ wheat). The application of fertilizer (RDF) also enhanced the population of actinomycetes might be due to supply of nutrient. Finding of Bharadwaj \& Omanwar (1992) also show the enhancement of microbial population with application of fertilizer. Among the soil under different treatment combination the maximum population of actinomycetes registered when chemical fertilizer was integrated with 30 ton $^{-1}$ hectare sewage sludge followed by 20 ton $^{-1}$ sewage sludge. The increment in the population of actinomycetes may be due to application of sewage sludge and release of nutrients (Selvi et al., 2005; Singh et al., 2014).

\section{Conclusions}

The result of the study revealed a significant increase in the population of microorganism that is bacteria, fungi and actinomycetes with application of sewage sludge along with chemical fertilizers. A significant increase in population of micro-organism and during the initial years which subsequently declined with time because of sewage sludge was applied only in $I^{\text {st }}$ rice crop.

\section{Conflict of Interest}

The authors declare that there is no conflict of interest regarding the publication of this research paper. 


\section{References}

Bharadwaj V, Omanwar PK (1992) Impact of long term fertility treatments on bulk density, water content and microbial population of soil. Journal of the Indian Society of Soil Science 40: 553-555.

Chhonkar PK, Bhadraray S, Patra AK, Purakayastha TJ (2002) Experiments in Soil Biology and Biochemistry. Westville Publishing House, New Delhi, Pp.180.

Cieślik BM, Namieśnik J, Konieczka P (2015) Review of sewage sludge management: standards, regulations and analytical methods. Journal of Cleaner Production 90: 1-15.

Duncan DM (1955) Multiple range and multiple F-test. Biometric 11: $1-42$.

Jackson ML (1973) Soil Chemical Analysis. Prentice Hall of India Pvt. Ltd., New Delhi.

Jatav HS, Singh SK, Singh YV, Paul A, Kumar V, Singh P, Jayant $\mathrm{H}$ (2016) Effect of biochar on yield and heavy metals uptake in rice grown on soil amended with sewage sludge. Journal of Pure and Applied Microbiology 10: 1367-1377.

Kamlesh K, Mishra MM, Dhankar SS, Kapoor KK, Gupta AP (1991) Effect of long term manurial application on microbial biomass. Journal of the Indian Society of Soil Science 39: 685688.

Lal R (2016) Global food security and nexus thinking. Journal of Soil and Water Conservation 71: 85A-90A.

Lal R, Follett RF, Stewart BA, Kimble JM (2007) Soil carbon sequestration to mitigate climate change and advance food security. Soil Science 172: 943-956.

Latare AM, Kumar O, Singh SK, Archana G (2014) Direct and residual effect of sewage sludge on yield, heavy metals content and soil fertility under rice-wheat system. Ecological Engineering 69: 17-24.

Latare AM, Singh SK (2013) Effect of sewage sludge and fertilizers application on accumulation of heavy metals and yield of rice (Oryza sativa L.) in an Inceptisol of Varanasi. Journal of the Indian Society of Soil Science 61: 219-225.

Magdoff F, VenEs H (2009) Building soils for better crops sustainable soil management. Sustainable Agriculture Research and Education ( $3^{\text {rd }}$ Edition) Pp 310.

Mahajan S, Kanwar SS, Kumari P, Sharma SP (2007) Long term effect of mineral fertilizers and amendments on microbial dynamics in an Alfisol of Klestern Himalayas. Indian Journal of Microbiology 47: 86-89.
Martin JP (1950) Use of acid rose Bengal and Streptomycin in the plate method for estimating soil fungi. Soil Science 69: 215.

Olsen SR, Cole CV, Watanabe FS, Dean LA (1954) Estimation of available phosphorus in soil by extraction with sodium bicarbonate. United State Department of Agriculture Circular 939: 19.

Rajasree G, Piliai GR (2002) Influence of nitrogen nutrition on soil microbial population. Annals of Agricultural Research 23: 331-333.

Selvi D, Santhy P, Dhakshinamoorthy M (2005) Effect of inorganic alone and in combination with farm yard manure on physical properties and productivity of vertic Haplusteps under long-term fertilization. Journal of the Indian Society of Soil Science 53: 302-307.

Sharma U, Subehila SK (2014) Effect of long term integrated nutrient management on rice (Oryza sativa $\mathrm{L}$.)- Wheat (Triticum aestivum L.) productivity and soil properties in North Western Himalayas. Journal of Indian Society of Soil Science 62: 248-254.

Singh SK, Singh RP, Bohra JS, Srivastava JP, Singh SP, Kumar M, Kumar O (2014) Effect of Organic and Inorganic Sources of Nutrients on Heavy Metals Content and Microbial Population in Soil under Rice Cultivation. Environment \& Ecology 32: 907-910.

Smith SR (2009) A critical review of the bioavailability and impacts of heavy metals in municipal solid waste compost compared to sewage sludge. Environment International 35: 142156.

Sparks DL (1996) Methods of soil analysis. Part 3- Chemical Methods. Soil Science Society of America, Inc. American Society of Agronomy, Inc. Madison Wisconsin, USA.

Subbiah B, Asija GL (1956) Alkaline permanganate method of available nitrogen determination. Current Science 25: 259-260.

Thornton HC (1922) On the development of standardized agar medium for counting of soil bacteria with special regard to repression of spreading colonies. Annals of Applied Biology 9: 241.

United Nation (2015) United Nation Department of Economics and Social Welfare, Population Division, Revision of World Population Prospects dated 09/08/2017.

United Nations (2014) Revision of the World Urbanization Prospects. New York: UN Department of Economic and Social Affairs.

Walkley A, Black IA (1934) An examination of Degtjareff method for determining soil organic matter and a proposed modification of the chromic acid titration method. Soil Science 37: 29-37. 